\title{
Identification and characterization of the SARS-CoV-2 lineage B.1.1.7 upon the new outbreak of the COVID-19 in Ukraine in February 2021
}

\author{
V. I. Kashuba1 ${ }^{1}$, N. V. Hryshchenko ${ }^{1}$, G. V. Gerashchenko ${ }^{1}$, N. S. Melnichuk ${ }^{1}$, \\ T. V. Marchishak ${ }^{1}$, S. Yu. Chernushyn ${ }^{1}$, L. M. Chernenko², V. K. Liashko ${ }^{3}$, \\ Z. Yu. Tkachuk ${ }^{1}$, M. A. Tukalo ${ }^{1}$ \\ ${ }^{1}$ Institute of Molecular Biology and Genetics, NAS of Ukraine \\ 150, Akademika Zabolotnoho Str., Kyiv, Ukraine, 03143 \\ ${ }^{2}$ State Enterprise Center of Public Health of the Ministry of Health of Ukraine, \\ 41, Yaroslavska, Kyiv, Ukraine, 04071 \\ ${ }^{3}$ The Ministry of Health of Ukraine \\ 7, Hrushevskoho, Kyiv, Ukraine, 01601 \\ g.v.gerashchenko@imbg.org.ua
}

\begin{abstract}
Aim. To identify and characterize the SARS-CoV-2 variants, collected upon the new wave of COVID-19 outbreak in Ivano-Frankivs'k region of Ukraine, using the whole genome genotyping. Methods. The parallel whole genome sequencing was performed on the processed RNA, isolated from nasopharyngeal swabs of 19 patients, using an Ion GeneStudio S5 Plus System. Results. All the identified SARS-CoV-2 genotypes were referred to 20I/501Y.V1 clade, the variant VUI202012/01 GRY (the B.1.1.7 lineage). In the analyzed virus variants forty-seven various mutations were found. Besides the founder 20I/501Y.V1 missense mutations, several unique alterations were detected, including those in the S- and N-proteins of SARS-CoV-2, that might have clinical and epidemiological relevance. Conclusions. The current wave of the COVID-19 outbreak in Ukraine is associated not only with seasonal fluctuations in the virus transmission, but also with the emergence of more aggressive virulent variants, such as B.1.1.7, which basically displaced previous strains and affects the younger population.
\end{abstract}

Keyw or d s: SARS-CoV-2, whole genome genotyping, mutations

\section{Introduction}

The coronavirus disease 2019 (COVID-19) pandemic is one of the most imperative problems in the world for now. A virus, causing this disease, the severe acute respiratory syn- drome coronavirus 2 (SARS-CoV-2) quite quickly became more virulent and aggressive in the human population $[1,2]$. These features could be explained by the fact that SARS-

(C) 2021 V. I. Kashuba et al.; Published by the Institute of Molecular Biology and Genetics, NAS of Ukraine on behalf of Biopolymers and Cell. This is an Open Access article distributed under the terms of the Creative Commons Attribution License (http://creativecommons.org/licenses/by/4.0/), which permits unrestricted reuse, distribution, and reproduction in any medium, provided the original work is properly cited 
CoV-2, being a positive-sense single stranded RNA virus, demonstrates a high level of genome plasticity in the absence of the effective mechanisms for correcting replication errors. In other words, the sudden outbreak of the COVID-19 pandemic is caused mainly by mutated variants of SARS-CoV-2. The novel mutations, most probably, resulted in more aggressive clinical manifestation of COVID-19, affecting groups of people that have not been previously at high risk, such as young people and children [3]. Additionally, the emergence of new SARS-CoV-2 variants requires the correction of both, protocols of patient treatment and assessment of the effectiveness of antiviral drugs and vaccines $[4,5]$.

Since the beginning of the pandemic, strategies for the monitoring of mutations in SARSCoV-2 were actively developed around the world, to respond in a timely manner to the emergence o new strains. These strategies include optimization of the regular partial (Sanger) or whole genome (NGS, Nanopore, etc.) sequencing to detect variants of the virus in various groups of patients and mass-targeted testing (PCR, ELISA, etc.) of the population for the known dangerous SARS-CoV-2 mutations. Ukraine, being one of the largest countries in Central Europe with high population mobility, is at the high epidemiological risk of the COVID-19 pandemic. By mid-October 2020, a "British strain" (the B.1.1.7 lineage), that caused the third wave of the COVID-19 outbreak in Europe, was dominant in neighboring countries.

The aim of the present study was to identify and characterize the SARS-CoV-2 variants, obtained from Ivano-Frankivs'k region of Ukraine upon the new February 2021 wave of the COVID-19 outbreak, using whole genome genotyping.

\section{Material and Methods}

Patient samples. Nasopharyngeal swabs were collected on February 22, 2021 from 17 patients in seven districts of Ivavo-Frankivs'k region and two samples in Kyiv by the Center for Public Health of the Ministry of Health of Ukraine. Sampling was conducted in accordance with the Helsinki declaration and approved by the Ministry of Health of Ukraine in agreement with the Center for Public Health. IMBG Ethical Approval № 2/23.03.2021. All patients were hospitalized with acute respiratory symptoms and were positive for SARSCoV-2 by a specific qPCR test. The study group was created of randomly selected 17 samples from Ivavo-Frankivs'k region ( $8 \mathrm{fe}$ males and 9 males; 8 patients were younger than 60 years old) and 2 samples from Kyiv region (age and gender are unknown).

Isolation of the total RNA was performed, using a Virus DNA/RNA isolation kit (ZymoResearch, USA), according to the manufacturer protocol. cDNA synthesis was carried out with the use of SuperScript IV VILO Master Mix (INVITROGEN, USA). The targeted libraries for sequencing were prepared with the help of the SARS-CoV-2 specific primers pools 1 and 2 from an Ion AmpliSeq SARS-CoV-2 Research Panel (Thermo Fisher Scientific, USA), barcoded with an Ion Xpress $^{\mathrm{TM}}$ Barcode Adapters Kit and an Ion AmpliSeq Library Kit 2.0 (Thermo Fisher Scientific, USA), following the user guide recommendations. The final concentration of barcoded libraries was determined, using Ion Library TaqMan ${ }^{\mathrm{TM}}$ Quantitation Kit (Thermo 
Fisher Scientific, USA). Barcoded libraries were diluted and pooled equimolarly (140 $150 \mathrm{pM}$ of each library). Emulsion PCR was performed on One Touch 2 machine (Thermo Fisher Scientific, USA), followed by enrichment and loading onto the Ion S5 530 chip. NGS was performed on Ion GeneStudio S5 Plus System, according to the manufacturer protocols. Bioinformatic and statistical analyses were conducted by a Torrent Suite Software, using the SARS-CoV-2 Research Plug-in Package v1.3.0 (Thermo Fisher Scientific, USA). To assemble the SARSCoV-2 genome, a reference-based IRMA plugin report was used. Additional analysis of mutations of nucleotides and amino acids, phylogeny and genomic epidemiology were performed, using GISAID (www.gisaid.org) and Nextstrain SARS-CoV-2 resources.

\section{Results and Discussion}

The obtained results of next generation sequencing of 19 samples, followed by the GISAID analysis of the SARS-CoV-2 whole genome, revealed that all analyzed samples contained the "British variant" of the virus, VUI202012/01 GRY (the B.1.1.7 lineage, 20I/501Y.V1 clade).

Noteworthy, 47 different missense mutations were identified in the 19 sequenced genomes of SARS-CoV-2, in comparison with the hCoV-19/Wuhan/WIV04/2019 variant. Besides the founder 20I/501Y.V1 (EPI ISL_581117) mutations, several other unique alterations were detected, including those in the S- and N-proteins, that may be of clinical and epidemiological importance. The mutations, common with the B.1.1.7 variants, and individual unique mutations are shown in
Table 1 in comparison with the reference Wuhan coronavirus genome.

The most clinically relevant alteration in the studied Ukrainian variants of the SARS$\mathrm{CoV}-2$ genome is the N501Y mutation in the Spike protein. At first, it was detected in Great Britain more than one year ago [WHO. WHO SARS-CoV-2 variant - United Kingdom of Great Britain and Northern Ireland. https:// www.who.int/csr/don/21-december-2020-sarscov2-variantunited-kingdom/en (accessed Dec 22, 2020)]. This mutation is associated with an increased spread of transmission and high contagiousness all over the world, affecting the younger population more, than the previous virus variants [6]. All the virus genomes of Ukrainian patients contained the missense founder mutations in the Spike and $\mathrm{N}$ proteins, common for the B.1.1.7 variants. According to the GISAID data, the earliest full genome sequence of the B.1.1.7 with a high coverage was detected in United Kingdom (ID: EPI_ISL_581117). This sequence contains all founder B.1.1.7 missense mutations and has one unique substitution in the NSP9 protein (Table 1). Of note, the EPI_ISL_581117 genome does not contain yet the nonsense NS8 K68stop mutation, as well as 9 of Ukrainian genomes. This mutation was found later in sequences of the B.1.1.7 lineage.

We have to mention, that in British variant and in 10 of Ukrainian samples there is an earlier mutation G204R, in the 204 residue of the N-protein. It seems that these genotypes appeared earlier; hence, various minor mutations could now be detected, such as P822L, $\mathrm{P} 153 \mathrm{~S}, \mathrm{~S} 1670 \mathrm{~F}$ in NSP3; L75F in NSP5; A225V in NSP14; T307I and P621S in the Spike protein and E106stop in NS8. Thus, 
NS8_K68stop is one of the later founder mutations. Importantly, all Ukrainian virus genomes, that contained this mutation, had also the G204P mutation in the N-protein. In the GISAID database, 2 out of 55 Ukrainian virus sequences with the K68stop mutation in the NS8 protein also contained the G204R mutation, that indicates their earlier origin compared to the Ukrainian samples with a combination of mutations NS8_K68stop and N G204P. Hence, Ukrainian SARS-Cov-2 genomes of the B.1.1.7 lineage could be divided in two groups by the time of origin: "older" genotypes (10 samples out of 19 with the $\mathrm{N}_{-}$ G204R mutation) and "younger" ones (9 re- maining samples). In "younger" genomes an additional set of the minor mutations was detected (Table 1).

The results of the comparative phylogenetic analysis are presented in Figure 1. All samples in the B.1.1.7 lineage contain more than 30 mutations in a single virus genome.

For a more accurate analysis of the origin of the detected virus genome variants, the phylogenetic analysis was carried out, using the Nextstrain resource. The following reference samples from GISAID database were used:

1. Accession ID: EPI_ISL_581117 (Founder of B1.1.7 lineage, Table 1);

Table 1. The missense mutations in the B.1.1.7 and Ukrainian variants of the SARS-CoV-2 genome, in comparison with the reference genome hCoV-19/Wuhan/WIV04/2019

\begin{tabular}{|c|c|c|c|c|c|c|c|c|c|c|c|c|c|c|c|c|}
\hline \multirow{2}{*}{$\begin{array}{l}\text { Sample } \\
\text { number }\end{array}$} & \multirow{2}{*}{ GISAD ID } & \multicolumn{2}{|c|}{\begin{tabular}{|l|} 
Patient data \\
\end{tabular}} & \multirow[b]{2}{*}{ NSP2 } & \multicolumn{12}{|c|}{ SARS-CoV-2 proteins with aa changes } \\
\hline & & Gender & Age & & NSP3 & NSP5 & NSP6 & NSP9 & NSP12 & NSP13 & NSP14 & Spike protein & NS3 & NS7a & NS8 & $\mathrm{N}$ protein \\
\hline $\begin{array}{c}20 \mathrm{I} \\
\text { 501Y.V1 } \\
\text { B.1.1.7 ** }\end{array}$ & EPI_ISL_581117 *** & & & & $\begin{array}{c}\text { T183I, A } \\
890 \mathrm{D}, \mathrm{I} 1 \\
412 \mathrm{~T}\end{array}$ & & $\begin{array}{r}\text { S106del, } \\
\text { G107del, } \\
\text { F108del }\end{array}$ & $\mathrm{D} 78 \mathrm{~N} !$ & P323L & & & $\begin{array}{l}\text { H69del, V70del, } \\
\text { Y144del, N501Y, } \\
\text { A570D, D614G, } \\
\text { P681H, T716I, } \\
\text { S982A. D1118H }\end{array}$ & & & $\begin{array}{c}\text { Q27stop, } \\
\text { R52I, } \\
\text { Y73C }\end{array}$ & $\begin{array}{c}\text { D3L, } \\
\text { R203K, } \\
\text { G204R, S } \\
\text { 235F }\end{array}$ \\
\hline 142627 & EPI_ISL_1298474 & $\mathrm{F}$ & Un & - & - & - & - & - & - & - & - & P621S & - & - & - & - \\
\hline 142706 & EPI_ISL_1298480 & $\mathrm{M}$ & 70 & - & - & - & - & - & - & - & $\mathrm{A} 225 \mathrm{~V}$ & - & - & - & - & - \\
\hline 142638 & EPI ISL_1298482 & $\mathrm{M}$ & 23 & - & P822L & $\mathrm{L} 75 \mathrm{~F}$ & - & - & - & - & - & - & - & - & - & - \\
\hline 142660 & EPI ISL_ 1298481 & $\mathrm{~F}$ & 67 & - & $\mathrm{P} 153 \mathrm{~S}$ & - & - & - & - & - & - & - & - & - & - & - \\
\hline 142672 & EPI_ISL_1298488 & $\mathrm{M}$ & 60 & - & S1670F & - & - & - & - & - & - & - & - & - & - & - \\
\hline 142701 & EPI_ISL_1298484 & $\mathrm{M}$ & 45 & - & - & - & - & - & - & - & - & T307I & - & - & - & - \\
\hline 142702 & NA & $\mathrm{M}$ & 45 & - & - & - & - & - & - & - & - & - & - & - & - & - \\
\hline $00008^{*}$ & NA & Un & Un & - & - & - & - & - & - & - & - & - & - & - & - & - \\
\hline 142689 & EPI ISL_1298486 & $\mathrm{M}$ & 81 & T634I & - & - & - & - & - & - & - & - & - & - & E106stop & - \\
\hline 142659 & NA & $\mathrm{F}$ & 45 & gap & gap & - & - & - & - & - & - & - & - & - & E106stop & - \\
\hline 142658 & EPI ISL_1298476 & $\mathrm{M}$ & 90 & - & - & - & - & - & - & - & - & - & - & - & K68stop & G204P \\
\hline 142662 & EPI_ISL_1298477 & $\mathrm{F}$ & 61 & - & - & - & - & K84R & - & - & - & - & - & - & K68stop & G204P \\
\hline 142690 & EPI ISL_ 1298478 & $\mathrm{M}$ & 44 & - & L72F & - & - & - & - & - & - & - & - & E16D & K68stop & G204P \\
\hline 142695 & EPI_ISL_1298475 & $\mathrm{M}$ & 45 & & D226E & - & - & - & - & S74P & - & - & - & G38A & K68stop & G204P \\
\hline 142692 & EPI_ISL_1298479 & $\mathrm{F}$ & 62 & - & - & - & - & - & - & - & - & - & - & - & K68stop & G204P \\
\hline 142683 & EPI_ISL_1298487 & $\mathrm{F}$ & 43 & - & A $861 \mathrm{~V}$ & - & - & - & T912I & - & - & - & G172C & - & $\begin{array}{c}\text { P30L, } \\
\text { K68stop }\end{array}$ & G204P \\
\hline 142697 & EPI_ISL_1298485 & $\mathrm{F}$ & 28 & - & - & - & - & - & - & - & - & P807S & - & - & K68stop & G204P \\
\hline 142670 & EPI_ISL_1298483 & $\mathrm{F}$ & 87 & - & - & - & - & - & - & - & - & - & - & - & K68stop & G204P \\
\hline $00010^{*}$ & NA & Un & Un & - & - & - & - & - & - & - & - & - & - & - & K68stop & G204P \\
\hline
\end{tabular}

Notes: UN — unknown; gap — lack of nucleotide sequence; * - Kyiv samples; ** — common mutations for Ukrainian samples and the B.1.1.7 lineage founder, *** — the founder B.1.1.7 genotype, collection date 2020-09-21; Originating lab: Lighthouse Lab in Milton Keynes; Submitting lab: Wellcome Sanger Institute for the COVID-19 Genomics UK (COG-UK) consortium; Authors: The Lighthouse Lab in Milton Keynes and Alex Alderton, Roberto Amato, Sonia Goncalves, Ewan Harrison, David K. Jackson, Ian Johnston, Dominic Kwiatkowski, Cordelia Langford, John Sillitoe on behalf of the Wellcome Sanger Institute COVID-19 Surveillance Team. 
2. Accession ID: EPI_ISL_741665 (Founder of genotypes with NS8_K68stop): collection date: 2020; location: $\overline{\mathrm{UK}} /$ England; Originating lab: Centre for Enzyme Innovation, University of Portsmouth / Translational Research Laboratory, Portsmouth

Hospitals NHS Trust; Submitting lab: COVID-19 Genomics UK (COG-UK) Consortium; Authors: A. Beckett, Y. Bourgeois, G. Scarlett, S. Glaysher, S. Elliott, K. Bicknell, R. Impey, A. Lloyd, S. Wyllie, E. Butcher, A. Chauhan, S. Robson;

3. Accession ID: EPI_ISL_1119202 (Founder of genotypes with NS8_K68stop $+\mathrm{N}_{-}$ G204P):Collection date: 2020-11-09; location: Switzerland / Bern; Originating lab: Viollier AG; Submitting lab: Department of Biosystems Science and Engineering, ETH Zürich; Authors: C. Chen, S. Nadeau, I. Topolsky, E. Dermitzakis, K. Harshman, I. Xenarios, H.i Pegeot, L. Cerutti, D. Penet, P. Jablonski, L. Fuhrmann, D. Dreifuss, K. Jahn, C. Beckmann, M. Redondo, O. Kobel, C. Noppen, S. Seidel, N. S. de Souza, N. Beerenwinkel, T. Stadler;

4. Accession ID: EPI_ISL_831663 (Close to Ukraine more recent genotype with NS8 K68stop+G204P): Collection date: 2021-0112; location: Slovakia / Hurbanovo; Originating lab: Institute of Virology, Biomedical Research Center of the Slovak Academy of Sciences, Bratislava; Submitting lab: Faculty of Natural Sciences, Comenius University, Bratislava; Authors: K. Boršová, V. Čabanová, B. Brejová, V. Hodorová, S. F. Havliková, J. Kopáček, M. Ličková, L. Lukáčiková, M. Neboháčová, M. Sláviková, T. Vinař, B. Klempa, J. Nosek;

5. Accession ID: EPI_ISL_741706 (Founder of genotypes with NS8_E106stop): Collection date: 2020; location: UK / England;
Originating lab: Centre for Enzyme Innovation, University of Portsmouth / Translational Research Laboratory, Portsmouth Hospitals NHS Trust; Submitting lab: COVID-19 Genomics UK (COG-UK) Consortium; Authors: A. Beckett, Y. Bourgeois, G. Scarlett, S. Glaysher, S. Elliott, K. Bicknell, R. Impey, A. Lloyd, S. Wyllie, E. Butcher, A. Chauhan, S. Robson;

The phylogenetic analysis showed that SARS-Cov-2 variants in the Ukrainian study group have different origin. They could be divided into two large clusters, with and without the combination of mutational NS8 K68stop and N_G204P. These clusters could be further sub-divided into smaller groups. In the genome cluster bearing the combination of NS8_K68stop and N_G204P mutations, three samples belong to two different brunches. Thus, the samples 142690 and 142692 have a common ancestor (142670). This fact supports our assumption that the B.1.1.7 variants were circulating in Ukraine long enough to evolve from the common "Ukrainian" ancestor.

In the second cluster, the sample 142689 forms a brunch with the reference variant EPI ISL_741706. In both genomes there is the NS8_E106stop mutation, which is also present in the Ukrainian 142659 sample (this sequence was omitted from the phylogenetic analysis, due to several gaps in the NSP3 gene region). Importantly, this mutation (NS8_E106stop) was also present in the virus genome of the 595 B.1.1.7 lineage in GISAID, demonstrating the origin different from other B.1.1.7 variants.

Summarizing, we suggest that in the end of February 2021, the variants of the SARSCoV-2 of the B.1.1.7 lineage, that are different by the origin and the time of occurrence, pre- 
V. I. Kashuba, N. V. Hryshchenko, G. V. Gerashchenko et al.

\section{$\boldsymbol{A}$}

Built with nextstrain/ncov. Maintained by the Nextstrain team. Enabled by data from GISAID

Showing 28 of 3814 genomes sampled between Mar 2020 and Feb 2021. Filtered to Ukraine (35) (1) $\cap$ Dec 2019 to Feb 2021 ]
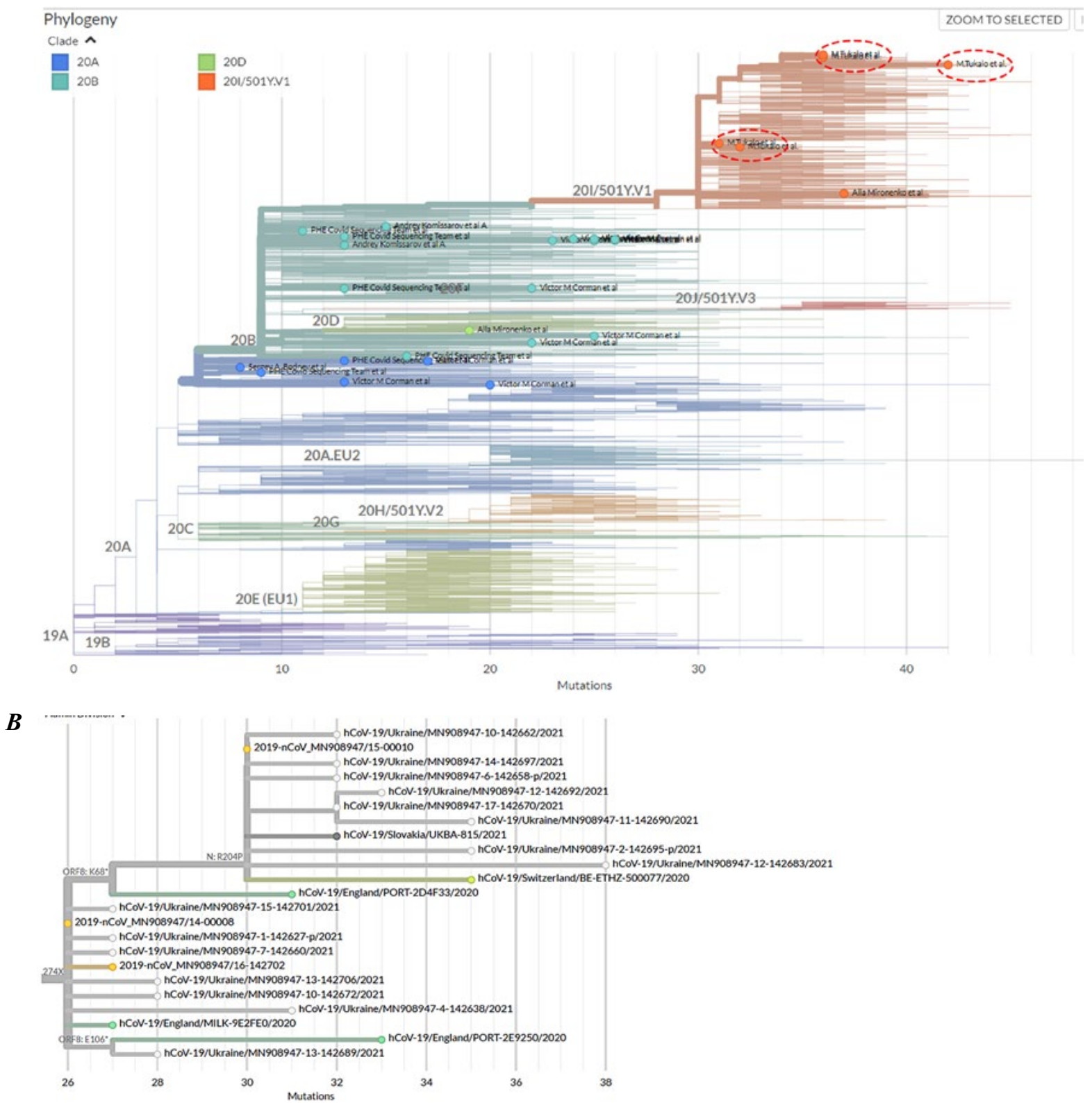

Fig. 1. $A-$ Genomic epidemiology of SARS-Cov-2 in Europe - a European phylogenetic tree till the end of February (GISAID); the Ukrainian samples from current study are in ovals in red. $B$ - A phylogenetic tree of the SARS-Cov-2 variants - global and current study focused subsampling: Ivano-Frankivs'k samples uploaded to GISAID are marked in light grey (current study); not uploaded to GISAID samples are marked in orange (current study); reference samples from GISAID are marked in other colors. 
vailed in Ukraine, although they were identified in Ukraine only in March 2021. Additionally, we propose that the "British variants" of the SARS-CoV-2 did not enter Ukraine at one time, since they have the recurrent origin.

The data on the genome sequencing of SARS-CoV-2 variants have been uploaded to the GISAID database (www.gisaid.org).

\section{Conclusions}

We think that the current wave of the COVID-19 outbreak in Ukraine is associated not only with seasonal fluctuations in the virus transmission, but also with the emergence of more aggressive virulent types of the B.1.1.7 variant in our country, that have replaced previous strains and are affecting younger population.

Based on the above, we suggest that the introduction of regular monitoring of genomic epidemiology of SARS-Cov-2 in Ukraine will improve the effectiveness of the anti-epidemiological measures and help to prevent new waves of the COVID-19 epidemic.

\section{Acknowledgements}

The authors would like to thank the Authors from the Originating laboratories for obtaining specimens as well as the Submitting laboratories where the genome data were generated and shared via GISAID, on which our research is based.

\section{Funding}

A part of this work was funded by the National Research Foundation of Ukraine in the framework of a project "Combined test systems for diagnosis and analysis of innate immunity gene expression upon dangerous viral infections"
(2020.01/0091) and by other scientific programs of the National Academy of Sciences of Ukraine.

Conflict of interest. The authors declare that they have no conflict of interest.

Statement of compliance with standards of research involving humans as subjects. All procedures carried out in the studies involving people were consistent with international and national standards, the Helsinki Declaration of 1964, and its later amendments, and approved by the Bioethics Commission of the Institute of Molecular Biology and Genetics, National Academy of Sciences of Ukraine (IMBG Ethical Approval protocol № 2/23.03.2021).

\section{REFERENCES}

1. Awadasseid A, Wu Y, Tanaka Y, Zhang W. SARSCoV-2 variants evolved during the early stage of the pandemic and effects of mutations on adaptation in Wuhan populations. Int J Biol Sci. 2021;17(1):97-106.

2. Giovanetti M, Benedetti F, Campisi G, Ciccozzi A, Fabris S, Ceccarelli G, Tambone V, Caruso A, Angeletti $S$, Zella D, Ciccozzi M. Evolution patterns of SARS-CoV-2: Snapshot on its genome variants. Biochem Biophys Res Commun. 2021;538:88-91.

3. Danchin A, Timmis K. SARS-CoV-2 variants: Relevance for symptom granularity, epidemiology, immunity (herd, vaccines), virus origin and containment? Environ Microbiol. 2020;22(6):2001-6.

4. Dos Santos $W G$. Impact of virus genetic variability and host immunity for the success of COVID-19 vaccines. Biomed Pharmacother. 2021;136:111272.

5. Amanat $F$, Krammer $F$. SARS-CoV-2 Vaccines: Status Report. Immunity. 2020;52(4):583-589.

6. Liu Y, Liu J, Plante KS, Plante JA, Xie X, Zhang X, $K u Z$, An Z, Scharton D, Schindewolf C, Menachery VD, Shi PY, Weaver SC. The N501Y spike substitution enhances SARS-CoV-2 transmission. bioRxiv [Preprint]. 2021:2021.03.08.434499. 
Ідентифікація та характеристика штаму В.1.1.7 SARS-CoV-2 при новому спалаху у лютому 2021 COVID-19 в Україні

В. I. Кашуба, Н. В. Грищенко, Г. В. Геращенко, Н. С. Мельничук, Т. В. Марчишак, С. Ю. Чернушин, Л. М. Черненко, В. К. Ляшко, 3. Ю. Ткачук, М. А. Тукало

Мета. Виявити та охарактеризувати штами SARSCoV-2, зібрані під час нової хвилі спалаху COVID-19 в Івано-Франківській області України, використовуючи повногеномне генотипування вірусу. Методи. Секвенування нового покоління вірусного геному проводили на тотальній РНК, виділеній з мазків носоглотки 19 пацієнтів, за допомогою системи IonGeneStudioS5Plus. Результати. Всі ідентифіковані генотипи SARS-CoV-2 були віднесені до класу 20I/501Y.V1, варіант VUI202012/01GRY (штам В.1.1.7). В аналізованих варіантах вірусу було виявлено сорок сім різних мутацій. Окрім місенс-мутацій, характерних для засновника 20I/501Y.V1, було виявлено кілька унікальних змін, у тому числі в S- та N-білках SARS-CoV-2, які можуть мати клінічну та епідеміологічну значимість. Висновки. Сучасна хвиля спалаху COVID-19 в Україні пов'язана не тільки із сезонними коливаннями передачі вірусу, але і з появою більш агресивних вірулентних варіантів, таких як В.1.1.7, який в основному витіснив попередні штами і здатен уражувати більш молоде населення.

Кл ю ч о в і сл о в а: SARS-CoV-2, повногеномне генотипування, мутації

\section{Идентификация и характеристика штамма B.1.1.7 SARS-CoV-2 при новой вспышке в феврале 2021 COVID-19 в Украине}

В. И. Кашуба, Н. В. Грищенко, А. В. Геращенко, Н. С. Мельничук, Т. В. Марчишак, С. Ю. Чернушин, Л. Н. Черненко, В. К. Ляшко, 3. Ю. Ткачук, М. А. Тукало

Цель. Выявить и охарактеризовать штаммы SARSCoV-2, собранные во время новой волны вспышки COVID-19 в Ивано-Франковской области Украины, используя полногеномное генотипирование вируса. Методы. Секвенирование нового поколения вирусного генома проводили на тотальной РНК, выделенной из мазков носоглотки 19 пациентов, с помощью системы IonGeneStudioS5Plus. Результаты. Все идентифицированые генотипы SARS-CoV-2 были отнесены к классу 20I/501Y.V1, вариант VUI202012/01GRY (штамм B.1.1.7). В рассматриваемых вариантах вируса было обнаружено сорок семь различных мутаций. Кроме миссенс-мутаций, характерных для основателя 20I/501 Y.V1, было обнаружено несколько уникальных изменений, в том числе в S- и N-белках SARS-CoV-2, которые могут иметь клиническую и эпидемиологическую значимость. Выводы. Современная волна вспышки COVID-19 в Украине связана не только с сезонными колебаниями передачи вируса, но и с появлением более агрессивных вирулентных вариантов, таких как В.1.1.7, который в основном вытеснил предыдущие штаммы и способен поражать более молодое население.

Кл ючевы е сл о в а: SARS-CoV-2, полногеномное генотипирование, мутации

Received 20.02.2021 